\title{
Opinions of the students of the School of Business Administration of the Silesian University in Karvina on the application of the key functions of Balint groups in self-coaching
}

\section{Dagmar Svobodová}

\section{Klíčová slova:}

sebekoučování, funkce Balintovské skupiny, myšlenková mapa, obsahová analýza názorů, studenti, komunikační problémy, interpersonální vztahy

\section{Key words:}

self-coaching, Balint group function, mind map, content analysis of opinions, students, communication problems, interpersonal relations

\begin{abstract}
Abstrakt
Předložená stat' analyzuje názory studentů OP fakulty Slezské univerzity v Karviné na uplatnění Balintovských skupin při sebekoučování. Úvod popisuje Balintovské skupiny jako jednu $\mathrm{z}$ forem skupinové pomoci při řešení komunikačních problémů v interpersonálních vztazích. První část statě vyjasňuje klíčové funkce Balintovských skupin při sebekoučování. Druhá část statě charakterizuje výběrový soubor koučovaných studentů v Balintovských skupinách z hlediska pohlaví, věkové kategorie a oborové specializace. Třetí část statě tvoří kvantitativní analýza názorů získaných obsahovou analýzou z osobních myšlenkových map koučovaných studentů. V závěru statě je potvrzen význam tvorby myšlenkových map $\mathrm{k}$ formování reálných představ koučovaných studentů o uplatnění Balintovských skupin jako skupinové pomoci při řešení komunikačních problémů v interpersonálních vztazích.
\end{abstract}

\begin{abstract}
The paper presented analyzes the opinions of the students of the School of Business Administration of the Silesian University in Karvina on the utilization of Balint groups in self-coaching. The introduction describes Balint groups as one of the forms of group assistance in the resolution of communication problems in interpersonal relations. The first part of the paper clarifies the key functions of Balint groups in self-coaching. The second part of the paper characterizes a sample of coached students in Balint groups from the perspective of sex, age category and professional specialization. The third part of the paper consists of a quantitative analysis of opinions acquired by content analysis from personal mind maps of coached students. The final part of the paper confirms the significance of the creation of mind maps for the formation of realistic ideas by the coached students regarding the application of Balint groups as group assistance in the resolution of communication problems in interpersonal relations.
\end{abstract}

\section{Introduction}

The goal of the self-coaching was to open the doors to more effective communication for students at the School of Business Administration of the Silesian University in Karvina. The goal set was fulfilled by an interactive program of Balint groups within the conception of the coaching culture of the company QED GROUP, a.s., which accompanied the students in the resolution of communication problems in interpersonal relations. During interactive lectures on Professional Counseling and Career Counseling, in which the students participated within the context of self-coaching, they communicated in Balint groups about interpersonal relations and searched for the answer to the question: How can the key functions of Balint 
groups be applied in the resolution of communication problems in interpersonal relations? Balint groups were also attended by students that were not dealing with any communication problems at the time. The output of the students' self-coaching was personal mind maps about the key functions of Balint groups. ${ }^{1}$ In Buzan's approach mind mapping was a useful visual tool for coached students for creating a realistic idea regarding group assistance in the resolution of communication problems in interpersonal relations. The coached students expressed their opinions onto the personal mind maps as notes in a structured way on an A4 sheet of paper. (see the Appendix) By creating mind maps as a visual tool that contains more information than regular text, the coached students learned to orientate themselves in the key functions of Balint groups as one of the forms of group assistance. A personal mind map is usable for coached students under the assumption that they know how to work with it, i.e., that they understand its design and they can create it so that it is easy-to-read. Based on the content analysis of the structured records of the opinions of students from the format of personal mind maps it appears that in self-coaching students are able to clarify the key functions of Balint groups, respectively to create a realistic idea about the structure and content of group assistance in the resolution of communication problems in interpersonal relations.

\section{Key functions of Balint groups in the self-coaching of students}

In the book Psychologie sebekoučování. Pohádka o ztracené krajině [Psychology of selfcoaching. A fairy tale about a lost land, Bahbouh (2010) describes the contexts of coaching and self-coaching. He states, ${ }^{2}$ that its objective is to help the coached individual effectively reach his or her set goal. According to Bahbouh, the ability of the coached individual to perform work is given by his or her energy, but not all energy has to transform into a result. The coached individual can strive for something, but he or she may be unsuccessful in the long-term; at other times the coached individual reaches the same effect quickly. Bahbouh explains the fluctuation of performance as a fact that the coached individual is aware of. But the coached individual may accept the given fact as chance that cannot be influenced. In Bahbouh's opinion, understanding the fluctuation of performance is influenced by how the coached individual handles his or her own energy. With reference to the performance fluctuation of a coached individual, Bahbouh formulates an equation within the concept of a relationship that explains the essence of coaching. Bahbouh sees the said equation as a physical law: WORK = PERFORMANCE x TIME. He considers the given relationship as understandable, just as the fact that the distance covered is a product of speed and time. Bahbouh emphasizes that whereas time goes by in a regular rhythm, the performance of a coached individual ranges greatly. From this it follows that performance changes among coached individuals are significant and difficult to understand. On what is the performance of coached individuals actually dependant? With reference to the link between performance and

\footnotetext{
${ }^{1}$ Mind maps and mind mapping were applied for the first time in 1942 by Tony Buzan for developing the ability to think. (see DEMBOWSKI, S., et al. Sedm kroků efektivního koučován [Seven steps of effective coaching]. $1^{\text {st }}$ edition. Brno: Computer Press, 2009, pg. 212. ISBN 978-80-251-1897-9.)

${ }^{2}$ BAHBOUH, R. Psychologie sebekoučování. Pohádka o ztracené krajině [Psychology of self-coaching. A fairy tale about a lost land] $1^{\text {st }}$ edition. Prague: Qed Group, 2010, pg. 13-14. ISBN 978-80-861149-61-5.

MUDR. Mgr. Radvan Bahbouh, Ph.D. is a psychologist and mathematician. Since 1995 he has lectured at the Department of Psychology of the Charles University Faculty of Philosophy on the methodology of psychology, psychometry and psychodiagnostics theory. He founded and manages the company QED GROUP, a.s., which offers psychology services to companies and individuals. On a long-term basis, he is theoretically and practically engaged in psychological coaching.
} 
external stimulation, Bahbouh states ${ }^{3}$ that with the increasing of external stimulation performance escalates until optimum performance is reached, but any further increases of external stimulation decrease the coached individual's performance. Bahbouh imagines a low level of activation as a boring situation, a high level of activation as a stressful situation, and in between he finds the optimal zone. Bahbouh calls external stimulation external motivation and notes that coached individuals utilize internal motivation more frequently as a part of various activities. A coached individual undertakes various activities because he or she is interested in doing so and increased motivation leads to his or her more convincing results. In Bahbouh's opinion, this fact is encapsulated in the coaching equation: WORK RESULT = MOTIVATION x TIME.

Bahbouh speaks of self-coaching as a technique that is very close to coaching ${ }^{4}$ and the coached individual is also the coach. In Bahbouh's opinion, it is typical for self-coaching that by asking questions the coached individual attains better awareness of what he or she actually wants and thanks to this the individual heads where he or she needs. In connection with better awareness, Bahbouh notes it was Socrates who started to favor asking questions ahead of explanations. But according to Bahbouh, philosophical questions were complicated and did not help the coached individual orientate his or her everyday steps. Only later was it possible to meet with planned change and the development of one's own personality. In connection with the development of one's own personality, Bahbouh states that one of the first people to raise and implement the idea of self-improvement was Franklin. Franklin created his own plan how to systematically work on personal characteristics. He designed a simple and functional system of self-coaching that he built on these questions: What good will I do today? and What good have I done today? With reference to Franklin, Bahbouh notes that self-coaching can also be used as a part of group assistance. One of the forms of group assistance for dealing with communication problems in interpersonal relations is Balint groups. The method was developed at the Tavistock Clinic in London in the 1950's by Michael Balint, a British psychoanalyst of Hungarian origin. Balint groups were originally used for the group resolution of interpersonal problems of medical staff with patients. Personality support and development were focused on the interpersonal relationship of the doctor/therapist and patient/client. They taught the doctors to listen and view the patient as a partner in dialogue and to view the patient's personality holistically as a bio-psycho-social unit. Balint acted therapeutically in the interpersonal relationship with the patients and communicated with them in the spirit of: Add minutes, you will save hours, whether for yourself or for my colleagues. ${ }^{5}$ Balint was thus one of the first pioneers of psychosomatic medicine. Interpersonal relations between the doctor and patient are cultivated and ripen in Balint groups, thus enabling doctors and patients to take a responsible stance towards coping with illness. In Balint groups doctors find support, other perspectives on their work and inspiration from their colleagues. Interpersonal relations do not have to be limited only to the medical profession, but they can also be used in other spheres of human activity. Balint groups serve as supervisory groups of interpersonal relations between clients and providers of services in the caring professions. They first spread in social work and Balint groups are used here in the

\footnotetext{
${ }^{3}$ BAHBOUH, R. Psychologie sebekoučování. Pohádka o ztracené krajině [Psychology of self-coaching. A fairy tale about a lost land] $1^{\text {st }}$ edition. Prague: Qed Group, 2010, pg. 15-16. ISBN 978-80-861149-61-5.

${ }^{4}$ BAHBOUH, R. Psychologie sebekoučování. Pohádka o ztracené krajině [Psychology of self-coaching. A fairy tale about a lost land] $1^{\text {st }}$ edition. Prague: Qed Group, 2010, pg. 59-60. ISBN 978-80-861149-61-5.

${ }_{5}^{5}$ PAČESOVÁ, M. Lékař, pacient a Michael Balint [Doctor, patient and Michael Balint]. $1^{\text {st }}$ edition. Prague: Triton, 2004, pg. 76. ISBN 80-7254-491-8.
} 
form of supervision with a precisely structured program. ${ }^{6}$ Simple and well-planned rules make it possible to transfer maximum experience for handling specific situations, without the occurrence of personal conflicts and negative feelings between the participants arising from mutual teaching.

At QED GROUP, a.s., the first step in a Balint group is the proposal and collection of topics, where the goal is to get inspiration for communication with the coached individual. The second step is an agreement on the order of topics. The third step is establishing a facilitator that monitors the time and compliance with the Balint group structure, which consists of five phases: ${ }^{7}$

1. Brief history and description of the topic (5 minutes) In the first phase the coached individual speaks about the topic/case, does not limit him or herself to just the facts, but states all circumstances and feelings that can help others become acquainted with the topic/case and understand it, or the coached individual asks the Balint group a question to which he or she would like to hear the answer.

2. Informative questions (10 minutes) In the second phase the other Balint group participants ask about the details and context of specific work within the topic/case. The topic of the Balint group is clarified and further specified during the discussion with the coached individual.

3. Brainstorming "I have a fantasy that..." (12 minutes) The Balint group participants share their fantasies that they have about the given topic/case. The fantasies can be related to what is happening inside each participant as well as in the group. The coached individual, whose topic/case is being discussed, is in the hot seat, which means that he or she is not allowed to express him or herself regarding the participants' fantasies, if possible not even non-verbally.

4. Non-directive intervention in the form of opinions: "If I was in his or her place, then I would ..., it reminds me of my situation with ..., I have already come across a similar situation and I handled it this way or that way, in this situation I would probably feel this way or that way..." (12 minutes). The Balint group participants propose interventions regarding the presented work with the topic/case. They say which specific steps they would take in the coached individual's position, but they do not give advice, blame or judge the coached individual. They communicate in the third person singular, so that they do not pull the coached individual (who is still obligated to remain silent) into the discussion.

5. Last word (5 minutes) In the final phase the coached individual speaks about what he/she found interesting, with what he/she agrees or does not agree, what he/she felt like during the Balint group. The coached individual can also state any additional facts of the topic/case that he/she only became aware of during the session. He/she concludes the Balint group by stating what the session gave him/her and what he/she intends to do. The coached individual can use the form of feedback + delta, where he/she confirms the positive intervention ideas in the sense of: "What I liked about the recommendations, but what could be even better."

At QED GROUP, a.s., a Balint group has 8-15 members and one facilitator. Participants bring to a Balint session problematic cases from their own coaching practice, with which the group

\footnotetext{
${ }^{6}$ BURYOVÁ, I. Etické aspekty v pomáhajících profesích [Ethical aspects in caring professions]. In MALÁTEK, V., et al. Sociálně ekonomické a manažerské aspekty podnikatelské etiky [Socio-economic and managerial aspects of entrepreneurial ethics]. Bratislava: Eurounion, 2008, pg. 11-33. ISBN 978-80-89374-00-7.

${ }^{7} \mathrm{http}: / /$ new.qedgroup.cz/produkty/jednotlivec/supervize-pro-kouce/ (17. 8. 2010).
} 
works intensively under the facilitator's guidance. It is a supervisory seminar where the center of attention is a delicate web of interpersonal relations, emotions, experiences and motives that the participants are experiencing in the relationship. The participants bring relationship constellations with which they need help. The goal of the Balint group is to help them change the situation and find new ways of resolution. Balint groups make it possible for their members to support one another, share experiences and contribute with practical suggestions towards the resolution of problems and difficult situations that they are encountering in their coaching practice. The group work heads towards better orientation in complicated interpersonal relations and deals only with relationship and communication problems, and not legislative or organizational problems. Balint groups are not only attended by persons with a specific topic, but also by their colleagues that are not dealing with any acute cases at the moment. Work in a Balint group does not consist of advice or instructions, but it facilitates the possibility of different perspectives that the main protagonists, who are deeply emotionally engaged in the matter, are usually not capable of seeing. A new perspective leads the participants to new ways of dealing with the interpersonal topic. If a Balint group is well managed, it inspires the main protagonists of the relationship cases that are brought forth to find new starting points for solutions. In order to create a safe environment, a condition of participation is the preservation of confidentiality about information from the supervision (particularly about information related to the users of the services and supervision participants) and for a team leader's group, the participation of only one person from the organization. Regular participation, personal motivation, active cooperation with other group members and the willingness to offer one's ideas and suggestions are also necessary. The consent of all existing members of a Balint group is needed in order to accept a new member. ${ }^{8}$

\section{Sample of students in Balint groups}

The sample consists of students of the attendance based form of study at the School of Business Administration of the Silesian University in Karvina, who attended Professional Counseling (PPRP) and Career Counseling (PKAP) lectures during the summer semester of the 2009/2010 academic year ${ }^{9}$. The coached students, as the subject of the empirical probe, were selected for the sample by stratified selection. The stratified sample, which has a total of 259 respondents, is structured based on sex, age category and professional specialization. ${ }^{10}$ From the perspective of gender, there are 54 men in the stratified sample, which represents $21 \%$ of the sample respondents, along with 205 women, which represents $79 \%$ of the sample respondents. (see Graph 1)

\footnotetext{
${ }^{8}$ http://www.wdaporadenstvi.eu/balintovska (17. 8. 2010).

${ }^{9}$ Interactive lectures with activization activities within the context of coaching and self-coaching were replaced by traditional didactic approaches, which had been utilized earlier in the teaching of Professional Counseling and Career Counseling. Self-coaching of students in Balint groups was reflected in more effective communication of students focused on the development of interpersonal relations via changes in behavior, actions, language, gesticulation and facial expression.

${ }^{10}$ The regional (stratified) selection of measurable units is not performed randomly within the entire sample, but only within its specific parts, which are called strata. The breakdown into strata is performed based on selected characteristics that can be set artificially (e.g., strata according to education) or strata which reflect the natural differentiation of the sample (e.g., work groups in a company, study groups at a faculty). (see MALÁTEK, V. Metodologie marketingového výzkumu [Market research methodology]. $1^{\text {st }}$ edition. Karviná: OPF SU, 2001, pg. 23. ISBN 80-7248-119-3.)
} 


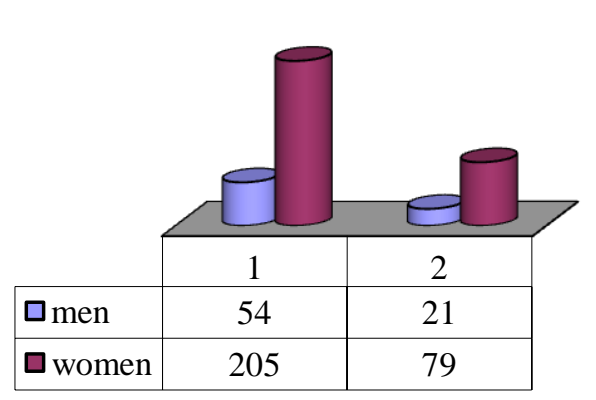

$\square$ men

$\square$ women

Source: own

Based on age category, there are 146 adolescents between the ages of 19-22 in the stratified sample, which represent $56 \%$ of sample respondents. The adolescents are attendance based students of bachelor's study programs of the School of Business Administration of the Silesian University in Karvina. There are 113 young adults in the 23-25 age category in the stratified sample, which represents $44 \%$ of sample respondents. The young adults are attendance based students of follow-up master's study programs of the School of Business Administration of the Silesian University in Karvina. (see Graph 2)

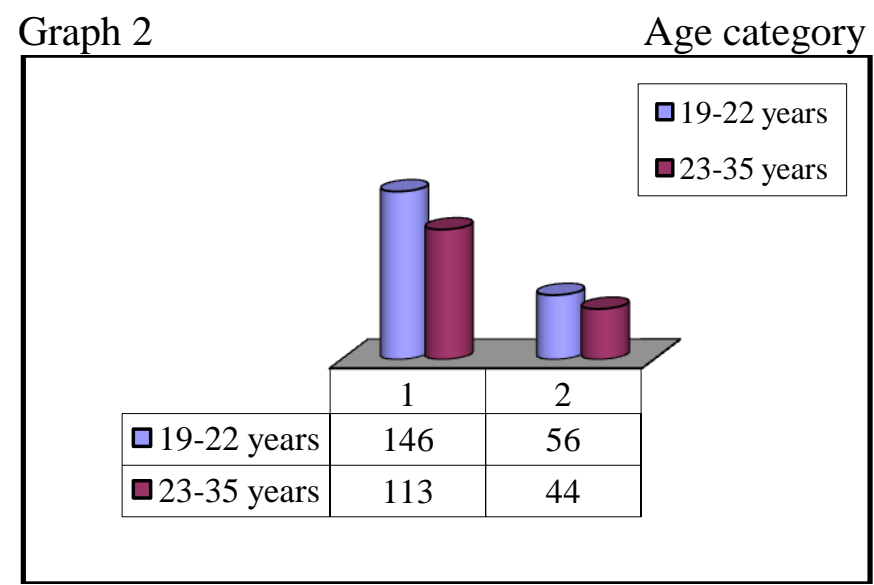

Source: own

From the perspective of professional specialization ${ }^{11}$, there are 111 students from the field of Marketing and Management in the stratified sample, which represents $43 \%$ of respondents. From the field of Tourism Industry Economics, there are 71 students in the stratified sample, which represents $27 \%$ of respondents. The field of Business Economics of Sales and Services is represented by 39 students in the stratified sample, which equals $15 \%$ of respondents. The field of Public Economics and Administration represents 27 students in the stratified sample, which equals $10 \%$ of respondents. There are 11 students in the stratified sample from the field of Social Management, which represents $4 \%$ of sample respondents. (see Graph 3)

\footnotetext{
${ }^{11}$ MM - Marketing and management, ECR - Tourism Economics, EKPO - Business Economics of Sales and Services, VES - Public Economics and Administration, SOMA - Social Management. (see the School of Business in Karvina. Information about studies. 2009-2010. Silesian University in Opava.)
} 


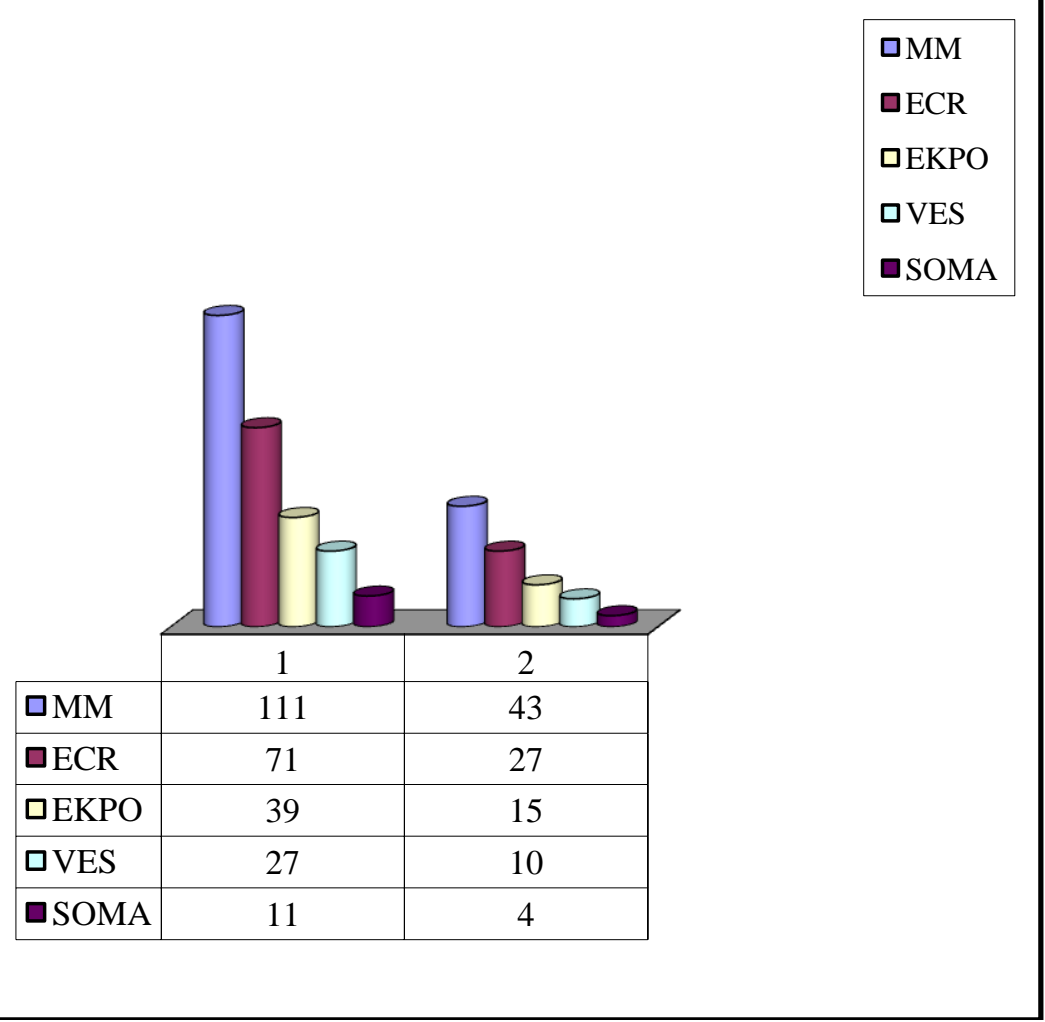

Source: own

\section{Quantification of the opinions of coached students from personal mind maps}

The content analysis of documents from the perspective of personification was used as the research method for performing the quantification of the opinions of coached students from their personal mind maps. ${ }^{12}$ How can the key functions of Balint groups be used in the resolution of communication problems in interpersonal relations? According to the structured notes of the opinions of coached students from the format of their personal mind maps, it appears that during self-coaching the students are able to clarify the key functions of Balint groups, respectively create a realistic idea about the structure and content of group assistance in the resolution of communication problems in interpersonal relations. The subject of the content analysis of personal mind maps are the key functions of Balint groups that are used in the forming of the realistic ideas of coached students about the structure and content of Balint groups as group assistance in the resolution of communication problems in interpersonal relations. Through the key functions of Balint groups during the self-coaching of students, their discussion topics were dealt with in the groups at the same time. The context of the quantification of the empirical data from the structured contents of the format of personal mind maps of coached students is unified into responses to the questions asked in contingency tables.

3.1 What topic did your Balint group deal with? (see Table 1)

3.2 Did the Baling group facilitator handle his/her role well? (see Table 2)

3.3 Did the topic carrier state the context and his/her feelings so that you were able to understand the topic? (see Table 3)

3.4 Did you have enough time for questions in the Balint group? (see Table 4)

12 MALÁTEK, V. Metodologie marketingového výzkumu [Marketing research methodology]. $1^{\text {st }}$ edition. Karviná: OPF SU, 2001, pg. 58-63. ISBN 80-7248-119-3. 
3.5 Did you have enough time for brainstorming in the Balint group? (see Table 5)

3.6 Did you give unnecessary advice to the topic carrier in the Balint group? (see Table 6)

3.7 Did you judge the topic carrier in the Balint group? (see Table 7)

3.8 Have you come across a situation similar to that of the topic carrier? (see Table 8)

Table 1

\begin{tabular}{|c|c|c|}
\hline Balint group topics & 1 & 2 \\
\hline $\begin{array}{l}\text { Communication during a specialized internship and with the leader of the } \\
\text { bachelor's/diploma thesis }\end{array}$ & 25 & 9.6 \\
\hline $\begin{array}{c}\text { Communication in the relationship between a university professor } \\
\text { and student }\end{array}$ & 15 & 5.7 \\
\hline Communication when staying and working abroad & 19 & 7.3 \\
\hline Communication when writing seminar papers and reports & 12 & 4.6 \\
\hline Communication in foreign languages & 33 & 12.7 \\
\hline Communication of a travel agency guide with clients & 9 & 3.4 \\
\hline $\begin{array}{l}\text { Employment interviews after graduation from the School of Business } \\
\text { Administration }\end{array}$ & 18 & 6.9 \\
\hline Communication within group cooperation & 4 & 1.5 \\
\hline $\begin{array}{c}\text { Communication in the acquisition of a competitive advantage of a } \\
\text { university student and graduate }\end{array}$ & 5 & 1.9 \\
\hline Communication while under stress & 12 & 4.6 \\
\hline $\begin{array}{l}\text { Communication in the accreditation of changes of School of Business } \\
\text { Administration study programs }\end{array}$ & 12 & 4.6 \\
\hline Communication at work while studying at university & 17 & 6.5 \\
\hline Communication of women that are discriminated against in the job market & 9 & 3.4 \\
\hline Communication and time management during the exam period & 13 & 5.0 \\
\hline Communication of students using the STAG information system & 15 & 5.7 \\
\hline $\begin{array}{l}\text { Communication structure of the School of Business Administration of the } \\
\text { Silesian University in Karvina }\end{array}$ & 21 & 8.1 \\
\hline $\begin{array}{l}\text { Communication during the community involvement of the School of } \\
\text { Business Administration students }\end{array}$ & 9 & 3.4 \\
\hline $\begin{array}{c}\text { Communication during the acquisition of funds for tuition for university } \\
\text { studies }\end{array}$ & 11 & 4.2 \\
\hline Total & 259 & 100 \\
\hline
\end{tabular}

Source: own

Table 2

Balint group facilitator's handling of his/her role

\begin{tabular}{|c|c|c|}
\hline Balint group facilitator's handling of his/her role & $\mathbf{1}$ & $\mathbf{2}$ \\
\hline Yes, the facilitator handled his/her role in the Balint group well & 249 & 96.1 \\
\hline I am not able to judge whether the facilitator handled his/her role in the Balint group well & 2 & 0.7 \\
\hline No, the facilitator did not handle his/her role in the Balint group well & 8 & 3.0 \\
\hline Total & $\mathbf{2 5 9}$ & $\mathbf{1 0 0}$ \\
\hline
\end{tabular}

Source: own

Table 3 Understanding of the context and feelings of the topic carrier by the Balint group

Understanding of the context and feelings of the topic carrier by the Balint group

Yes, the topic carrier stated the context and feelings in a way that enabled us to understand the topic

I am not able to judge whether the topic carrier stated the context and feelings in a way that enabled us to understand the topic

No, the topic carrier did not state the context and feelings in a way that enabled us to understand the topic

Total

\begin{tabular}{|c|c|}
\hline $\mathbf{1}$ & $\mathbf{2}$ \\
257 & 99.2 \\
1 & 0.3 \\
1 & 0.3 \\
\hline $\mathbf{2 5 9}$ & $\mathbf{1 0 0}$ \\
\hline
\end{tabular}

Source: own 
Table 4

Sufficient amount of time for questions in the Balint group

\begin{tabular}{|c|c|c|}
\hline Sufficient amount of time for questions in the Balint group & $\mathbf{1}$ & $\mathbf{2}$ \\
\hline Yes, there was enough time for questions in the Balint group & 250 & 96.5 \\
\hline I am not able to judge whether there was enough time for questions in the Balint group & 0 & 0 \\
\hline No, there was not enough time for questions in the Balint group & 9 & 3.4 \\
\hline Total & $\mathbf{2 5 9}$ & $\mathbf{1 0 0}$ \\
\hline
\end{tabular}

Source: own

Table 5

Sufficient amount of time for brainstorming in the Balint group

\begin{tabular}{|c|c|c|}
\hline Sufficient amount of time for brainstorming in the Balint group & $\mathbf{1}$ & $\mathbf{2}$ \\
\hline Yes, there was enough time for brainstorming in the Balint group & 238 & 91.8 \\
\hline I am not able to judge whether there was enough time for brainstorming in the Balint group & 2 & 0.7 \\
\hline No, there was not enough time for brainstorming in the Balint group & 19 & 7.3 \\
\hline Total & $\mathbf{2 5 9}$ & $\mathbf{1 0 0}$ \\
\hline
\end{tabular}

Source: own

Table 6

Giving unnecessary advice to the topic carrier in the Balint group

\begin{tabular}{|c|c|c|}
\hline Giving unnecessary advice to the topic carrier in the Balint group & $\mathbf{1}$ & $\mathbf{2}$ \\
\hline Yes, we gave unnecessary advice to the topic carrier in the Balint group & 10 & 3.8 \\
\hline I am not able to judge whether we gave unnecessary advice to the topic carrier in the Balint \\
group & 3 & 1.1 \\
\hline No, we did not give unnecessary advice to the topic carrier in the Balint group & 246 & 94.9 \\
\hline Total & $\mathbf{2 5 9}$ & $\mathbf{1 0 0}$ \\
\hline
\end{tabular}

Source: own

Table 7 Non-judgmental approach of members of the Balint group towards the topic carrier Non-judgmental approach of members of the Balint group towards the topic carrier Yes, we judged the topic carrier in the Balint group

I am not able to judge whether we judged the topic carrier in the Balint group No, we did not judge the topic carrier in the Balint group

Total

\begin{tabular}{|c|c|}
\hline $\mathbf{1}$ & $\mathbf{2}$ \\
\hline 11 & 4.2 \\
\hline 3 & 1.1 \\
\hline 245 & 94.5 \\
\hline $\mathbf{2 5 9}$ & $\mathbf{1 0 0}$ \\
\hline
\end{tabular}

Source: own

Table 8

Experience with a situation similar to that of the topic carrier

\begin{tabular}{|c|c|c|}
\hline Experience with a situation similar to that of the topic carrier & $\mathbf{1}$ & $\mathbf{2}$ \\
\hline Yes, I have come across a situation similar to that of the topic carrier & 136 & 52.5 \\
\hline I am not able to judge whether I have come across a situation similar to that of the topic carrier & 2 & 0.7 \\
\hline No, I have not come across a situation similar to that of the topic carrier & 121 & 46.7 \\
\hline Total & $\mathbf{2 5 9}$ & $\mathbf{1 0 0}$ \\
\hline
\end{tabular}

Source: own

3.9 How did the topic carrier, as the main participant of the group, experience the course of the Balint group?

The last question on the personal mind maps of coached students is formulated as open. ${ }^{13}$ The significance of the open question consists of the fact that the possibility of choosing an answer is delegated to the coached students, which leads to their positive motivation for structuring personal mind maps. There is little information about the key functions of Balint groups in the self-coaching of students as a research subject, and the open question here makes it possible to uncover more of the problem area. For the said reason the open question is used in the empirical probe of the opinions of coached students. One can assume that the given type of research is a stimulus for coached students to state in their personal mind maps the most

13 MALÁTEK, V. Metodologie marketingového výzkumu [Marketing research methodology]. $1^{\text {st }}$ edition. Karviná: OPF SU, 2001, pg. 54-55. ISBN 80-7248-119-3. 
significant empirical data that substantiate the application of the key functions of Balint groups in their self-coaching. During the introduction of Balint groups, the students -- as carriers of the topics -- were nervous because they were experiencing various communication and study problems at the School of Business Administration at the Silesian University in Karvina and these problems were not easy for them. ${ }^{14}$ However, the other students in the Balint group soon recognized that they have similar problems especially related to the specialized internships that are linked to the topics of the final theses that they will be defending as a part of the state final examinations. They appreciated the positive feedback that gave them new motivation towards their studies at the faculty as well as new ideas. They became aware of the fact that communication and study problems should be perceived as an inspiring challenge to the search for alternative solutions. For the said reason they very much appreciated examples from life abroad and the experiences presented from stays within the scope of the Erasmus study program. They found out about the advantages and disadvantages of Erasmus and they formed a realistic notion of how to improve their own language skills. The students, as topic carriers in Balint groups, understood how, based on examples from abroad, they can acquire new sources for financing their own university studies. Later their nervousness subsided and they returned to their normal state and they were perceived positively by the others in the Balint groups because they were action oriented and they perceived the course of the Balint group with enthusiasm and interest. They knew what the discussion was about because they had a good overview of the topics, they were concise, they identified with their topic and thoroughly enjoyed it. They came across as composed, relaxed, impartial, euphoric, concentrated, trustworthy, sincere, authentic, communicative (they listened actively, spoke smoothly), and they had no problems getting into the roles of the carriers of topics in the Balint groups that suited them. One can say that as the main participants in Balint groups they were perfectly at ease and fulfilled their function very well in the majority of cases. They handled their own emotions well, so the other students in Balint groups perceived their experience also emotionally, even excitedly, but with empathy. The students that were the topic carriers were willing to share their own feelings and they included the others in the Balint groups in discussions. In the inspiring atmosphere of Balint groups they were able to discuss, react promptly, flexibly, with a smile and they managed to cooperate actively and remain accessible. They discussed the opinions voiced, they were able to respond to the questions that were asked, they were interested in the observations of others, they appreciated their active participation, and they defended their own opinions with conviction and determination. They attempted to appear self-confident and make objective arguments in the discussion. They were interested in speaking more during the brainstorming, from which they took away a lot of interesting information, and they regretted that as participants in the hot seat they could not react immediately to the opinions expressed by others. An advantage of the Balint groups was that all the students knew each other, which enabled their quick engagement in the discussion and contributed to their interest in the valuable and pleasant discussion. The action oriented students in the Balint groups were a big advantage because they enjoyed the discussion when they were contemplating the opinions and comments of others. The topic carriers were satisfied with the outcome of the Balint group discussions and with the contributions of the other students. The students perceived the course of the Balint groups as very beneficial because they knew they were acquiring valuable experiences and knowledge. They also discovered that it is easier to participate in a discussion in a small group than in a medium or large group. The summary of the content of the

\footnotetext{
${ }^{14}$ MIZIA, A. C. Opowieść jako sposób nawiazania przerwanej komunikacji. In MARSZAŁEK, A. Komunikacja i edukacja - ku synergiczności porozumiewania sie. Zakopane: Adam Marszałek, 2009, pg. 132-140. ISBN 97883-7611-607-5.
} 
discussion by students that were the topic carriers took place appropriately and their final word did justice to the activity of the Balint groups. The answers of the topic carriers directed the other students in the Balint groups to their effective resolution. The only criticism that the students expressed was aimed at the occasional deviation from the main topic of the Balint group and to the insufficient opportunity for their own expression. Some Balint groups had a smaller amount of the information necessary to clarify the topic in a tough discussion, which in the end caused fatigue for several students when it was discovered that there was only a minimal chance to change anything. However, the minimal chance to change anything occurred with organizational and legislative problems. Here brainstorming was not very productive, even though some of the ideas from it could be used. Nevertheless the organizational and legislative problems were so complicated that there was not enough time to discuss the bases of their solutions in detail. In such cases the topic carriers had a tendency to join in the problem solving prematurely, or became preoccupied with themselves and did not take the opinions of others into account sufficiently.. However, most students agreed that Balint groups could be tried at the School of Business Administration at the Silesian University in more subjects. ${ }^{15}$ Balint groups worked in the style of team contemplation, particularly of communication and study problems, and everything went smoothly. The resolution of the topics discussed took place in the style of the brainstorming of ideas and opinions leading to the creative understanding of the essence of the problem while being supported by others. The content structure of Balint groups was suitable because it enabled the effective management of joint discussions and brought emotionally powerful experiences for the coached students.

\section{Conclusion}

The first goal of Balint groups in the self-coaching of students as a form of group assistance in the resolution of communication problems is to understand their interpersonal relations, where the need for increased sensitivity to the answer itself to the message arises. If the message of the coached student remains unnoticed and the coach reacts with a lack of understanding, a confusion of tongues occurs. By not dispersing their own responsibility, i.e.., not delegating responsibility to fellow students, coached students can learn better self-observation in Balint groups, as well as the observation of others and their own counter-transference. The coached students will understand the interpersonal relations among themselves only by accepting personal responsibility and remaining in mutual interaction. The second goal of Balint groups is overcoming the preconception that consists of the abandoning of the conviction that the coach knows best how the coached student should act and what is best for him or her. This concerns the overcoming of the paternalistic omniscience of the coach as a helper, because the Balint group makes it possible to resign from all of the coach's preconceived standpoints. The third goal of the Balint group consists of the effort to change oneself, which is connected with the clarification of the communication conflicts in one's own interpersonal relations. In Balint groups the issue is not the fundamental personality transformation of coached students. The issue is mainly their sensibility and feeling oneself into one's own counter-transference mechanisms, conscious, pre-conscious and unconscious experiences and discovering one's own fears. Conversely, some coached students need to learn how to behave assertively. By compulsively overtaking an excessive amount of responsibility, they block the opening of the communication problem in the Balint group. By becoming aware of the personal contribution to an interpersonal relationship with others, it is possible to change the handling of a

\footnotetext{
${ }^{15}$ MIKA, J. Kompetencje komunikacyjne andragogów Republiki Czeskiej. In MARSZAŁEK, A. Komunikacja i edukacja - ku synergiczności porozumiewania sie. Zakopane: Adam Marszałek, 2009, pg. 89-95. ISBN 978-837611-607-5.
} 
communication problem. Accepting one's own weaknesses and limits purifies the air in a Balint group and relaxes the tension of coached students towards themselves. Everything takes place with the constant awareness of the fact that in self-coaching the students are not looking for self-experiential training or a psychotherapeutic group because they are not patients but professionally improving individuals. The key functions of Balint groups are thus mastered by the coached students, who are expanding their professional skills by the ability to better understand interpersonal relationships with others. If the students have finer empathy, they will overcome communication problems more effectively and they will be able to renew trust more easily with their understanding. Inclusion in a Balint group assumes the performance of self-coaching, the willingness to work in a team during the semester and offer topics from one's own self-coaching for continuous work with fellow students. How can the key functions of Balint groups be applied in the resolution of communication problems in interpersonal relations? Utilization of the key functions of Balint groups in the self-coaching of students is beneficial for the resolution of communication problems in interpersonal relations. After they are placed into a Balint group, at first the coached students are dependent considerably on the facilitator. They want to know the single right answer to their mistakes and open discussions increase their uncertainty. But gradually they become aware of the significance of the interpersonal relationship in communication and possible damage in communication conflicts. For the said reason, the best starting point is the release from fear and creative modification of interpersonal relations. In a Balint group, the topic carriers experience their own specific position of a team member more sharply. In group assistance they come across fellow students who are not accustomed to talking about communication problems, yet they are aching for dialogue. The topic carriers learn to recognize which wishes and fears, hopes and disappointments the coached fellow students are transferring to them unconsciously. Other students perceive the specificity of group assistance in the fact that they frequently face communication problems alone, without the possibility of identifying with fellow students. For the said reason they hunger for the protection of a Balint group, because the solidarity critique in a Balint group makes it possible for them to recognize countertransference influences and the fear that they will not stand the test in interpersonal relations. Identification of coached students that are looking for group assistance in Balint groups represents an opportunity for the renewal of mutual interpersonal contacts after the communication problems have been resolved. The content analysis of the structured records of student opinions from the format of personal mind maps confirms that in self-coaching students are able to clarify the key functions of Balint groups, respectively to create a realistic idea about the structure and content of group assistance in the resolution of communication problems in interpersonal relations.

How to use a personal mind map at School of Business Administration of the Silesian University in Karvina in the future? Place the main topic in the center of the personal mind map. Distribute the individual parts of the personal mind map around the center and connect them to the center with lines. Branch parts of the personal mind map as needed. Using secondary lines or arrows, express on the personal mind map relationships that go across the hierarchy of the Balint group topic. Use colors, symbols and highlighting to make the personal mind map easier to read. Use short words and short phrases, focus on the structure of the main topic and linkages between the individual parts and do not waste energy on the formulation of sentences. During the structuring of the personal mind map, take a large piece of paper or attach another sheet with the goal of limiting the number of factors that prevent the concentration and creativity of coached students. 
Self-coaching then enables the students to reduce their over-engagement in communication. After completing a Balint session, they then act with more freedom and easily feel the sympathetic inclination in the behavior of others. Understanding their own partiality opens in the students' self-coaching the opportunity for balance and effective communication in interpersonal relations.

\section{Bibliography:}

[1] BAHBOUH, R. Psychologie sebekoučování. Pohádka o ztracené krajině [Psychology of self-coaching. A fairy tale about a lost land]. $1^{\text {st }}$ edition. Prague: Qed Group, 2010, 115 pg. ISBN 978-80-861149-61-5.

[2] BURYOVÁ, I. Etické aspekty v pomáhajících profesích [Ethical aspects in caring professions]. In MALÁTEK, V., et al. Sociálně ekonomické a manažerské aspekty podnikatelské etiky [Socio-economic and managerial aspects of entrepreneurial ethics]. Bratislava: Eurounion, 2008, pg. 11-33. ISBN 978-80-89374-00-7.

[3] DEMBOWSKI, S., KOL. Sedm kroků efektivního koučování [Seven steps of effective coaching]. $1^{\text {st }}$ edition. Brno: Computer Press, 2009, 224 pg. ISBN 978-80-251-1897-9.

[4] MALÁTEK, V. Metodologie marketingového výzkumu [Market research methodology]. $1^{\text {st }}$ edition. Karviná: OPF SU, 2001, 110 pg. ISBN 80-7248-119-3.

[5] MIKA, J. Kompetencje komunikacyjne andragogów Republiki Czeskiej. In MARSZAŁEK, A. Komunikacja i edukacja - ku synergiczności porozumiewania sie. Zakopane: Adam Marszałek, 2009, pg. 89-95. ISBN 978-83-7611-607-5.

[6] MIZIA, A. C. Opowieść jako sposób nawiazania przerwanej komunikacji. In MARSZAŁEK, A. Komunikacja i edukacja - ku synergiczności porozumiewania sie. Zakopane: Adam Marszałek, 2009, pg. 132-140. ISBN 978-83-7611-607-5.

[7] School of Business Administration in Karvina. Information about studies. 2009-2010. Silesian University in Opava.

[8] PAČESOVÁ, M. Lékař, pacient a Michael Balint [Doctor, patient and Michael Balint]. $1^{\text {st }}$ edition. Prague: Triton, 2004, 176 pg. ISBN 80-7254-491-8.

[9] http://new.qedgroup.cz/produkty/jednotlivec/supervize-pro-kouce/

[10] http://www.wdaporadenstvi.eu/balintovska

[11] Empirical probe of personal mind maps of coached students.

Klasifikace JEL: J6, J62

Mgr. Dagmar Svobodová, Ph.D.

odborný asistent Katedra společenských věd Obchodně podnikatelská fakulta v Karviné

Slezská univerzita v Opavě,

Univerzitní náměstí 1934/3, 73340 Karviná, svobodova@opf.slu.cz 


\section{。}

Personal mind map of a coached student

Appendix

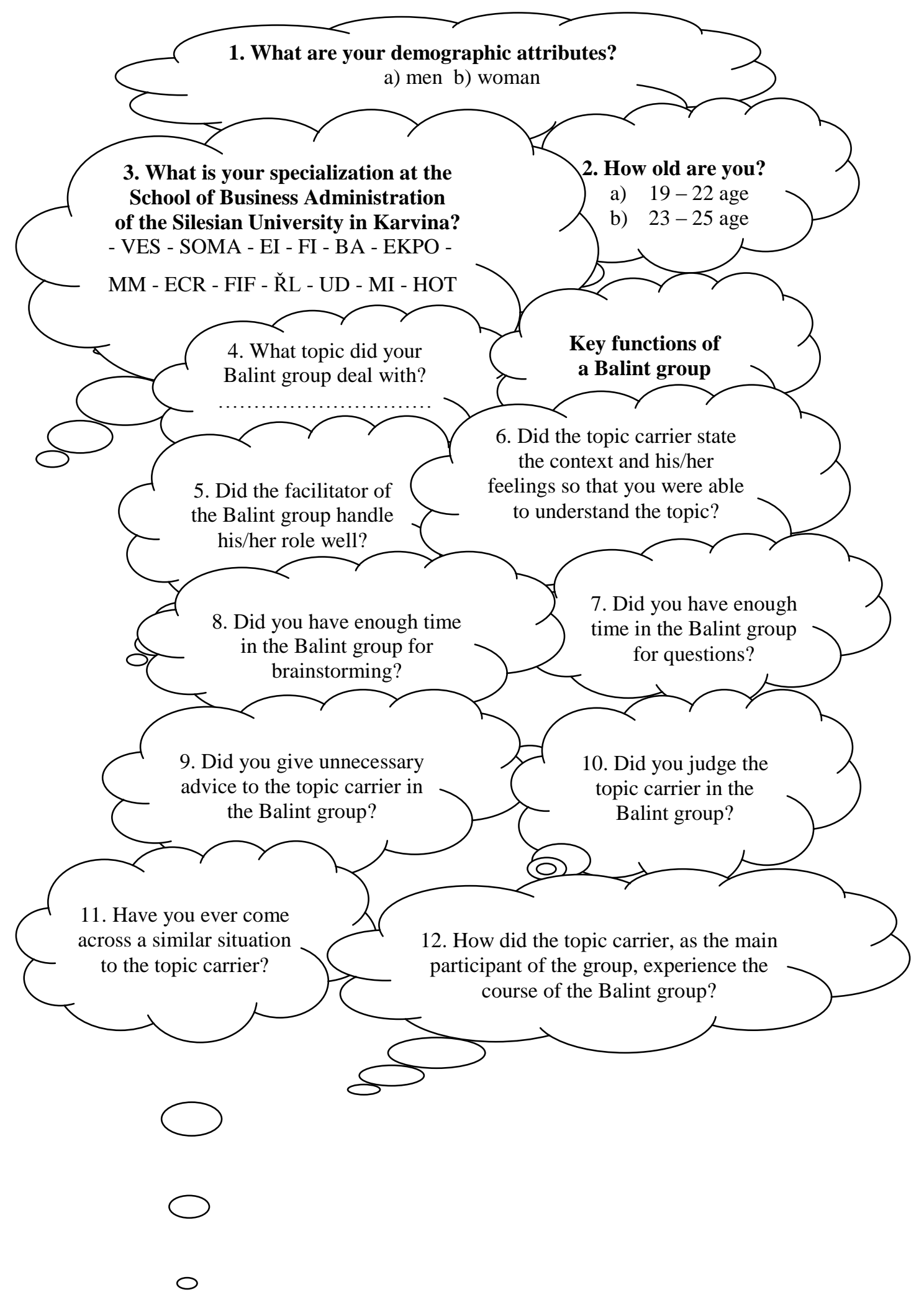

